\title{
KNOWLEDGE AND PERCEPTIONS OF PHARMACY STUDENTS TOWARDS TRAINING IN COMPLEMENTARY AND ALTERNATIVE HEALTH CARE
}

\section{Ilse Truter}

D Com, B Pharm, MSc, PhD

Registered Pharmacist

Associate Professor in Pharmacy and Head of Pharmacy Practice, Nelson Mandela Metropolitan University

Corresponding author: ilse.truter@nmmu.ac.za

Keywords: Complementary and Alternative Health Care (CAHC); pharmacy; South Africa; training; pharmacy curriculum

\begin{abstract}
Complementary and Alternative Health Care (CAHC) is the primary source of health care for over $70 \%$ of the world's population. The aim was to determine the knowledge and perceptions of undergraduate pharmacy students towards CAHC, as well as to establish their training needs for CAHC. A questionnaire survey was conducted amongst undergraduate pharmacy students during October 2002 at a South African pharmacy school. A total of 160 questionnaires were analysed. Senior students more accurately defined CAHC than first-and second-year students. Twenty CAHC therapies were listed and participants were asked to firstly indicate their level of knowledge, and secondly, their usage of these therapies. They were most knowledgeable with respect to herbalism (95.0\%), massage (90.6\%), traditional African medicine (81.3\%) and diet therapy (81.3\%). Massage was the therapy most often used (58.1\%), followed by herbalism (45.0\%). Ayurveda, iridology, colonic irrigation and naturopathy were the least often used therapies. Participants indicated that CAHC should be included in the third and fourth year of the $B$ Pharm degree. A need for undergraduate pharmacy students to be trained in the basic principles of CAHC, and for continuing education courses in $C A H C$, was identified. The current knowledge of pharmacy students regarding CAHC is inadequate.
\end{abstract}

\section{OPSOMMING}

Komplementêre en Alternatiewe Gesondheidsorg (KAG) is die hoofbron van gesondheidsorg vir meer as $70 \%$ van die wêreld se bevolking. Die doel was om die kennis en persepsies van voorgraadse aptekerswesestudente ten opsigte van KAG te bepaal, asook om hulle opleidingsbehoeftes vas te stel. ' $n$ Vraelysopname is onder voorgraadse aptekerswesestudente in Suid-Afrika gedurende Oktober 2002 uitgevoer. Altesaam 160 vraelyste is ontleed. Senior studente het KAG meer akkuraat as eerste- en tweedejaarstudente gedefinieer. Twintig KAG terapieë is gelys, en studente is versoek om eerstens hulle kennisvlak, en tweedens hulle gebruik, van die terapieë aan te dui. Hulle het die meeste kennis van kruiemedisyne (95.0\%), massering (90.6\%), tradisionele Afrika-medisyne (81.3\%) en dieetterapie (81.3\%) gehad. Massering was die terapie wat die meeste gebruik is (58.1\%), gevolg deur kruiemedisyne (45.0\%). Ayurveda, iridologie, kolon-irrigasie en naturopatie was die terapieë wat die minste gebruik is. Deelnemers het aangedui dat KAG in die derde en vierde jaar van die $B$ Pharm-graad ingesluit behoort te word. ' $n$ Behoefte aan die opleiding van voorgraadse aptekerswesestudente in die basiese beginsels van $K A G$, en vir voortgesette onderrigkursusse in KAG, is geïdentifiseer. Die kennis van aptekerswesestudente in verband met KAG is tans onvoldoende. 


\section{BACKGROUND AND PROBLEM DEFINI- TION}

The surge in interest in Complementary and Alternative Health Care (CAHC) is well documented in many Western countries and it is the primary source of health care for over $70 \%$ of the world's population (Ernst, Pittler, Stevinson \& White, 2001:ix). It has furthermore been stated that South Africa is catching up with the rest of the world in the CAHC field (Plusfile, 2000:1). Despite the fact that many of the CAHC therapies have been around for hundreds of years (Ernst et al. 2001:ix), there are limited sources of reliable information about whether they work or are safe. Although there is an abundance of claims being made about the curative powers of complementary therapies, there are a similar number of disclaimers being made about "quackery". The pharmacist, as a member of the health care team, has an important obligation to be informed and educated about the different $\mathrm{CAHC}$ therapies and must be in a position to counsel patients regarding the safety and efficacy of the different therapies.

This raised the question of whether pharmacy students are adequately trained in $\mathrm{CAHC}$ in their curriculum. A study conducted in the United States of America (USA) to examine pharmacy students' responses to a CAHC elective, showed an extremely positive response in favour of an alternative medicine elective (Miederhoff, Wright, Buruss \& Weaver, 1999:95). With the increased interest of the public in the USA in alternative health care practices, especially herbal products, pharmacists are being called upon to counsel on their use. According to Miller and Murray (1997:160-162) USA schools of pharmacy have been showing a renewed interest in natural product instruction with two-thirds of them reporting that they provide some form of instruction in this area. A South African study amongst nursing science lecturers in Port Elizabeth to establish their attitudes, comprehension and willingness to include alternative health care in the nursing curriculum showed that nursing science lecturers were in favour of including alternative health care in the nursing curriculum, but would not support clinical training in alternative health care (Ebey-Tessendorf, Kretzmann \& Mouton, 1997:17). No similar studies could be found for the pharmacy profession in South Africa.

The Rules Relating to Good Pharmacy Practice (GPP) that was published on 17 December 2004 (South Africa, 2004:87-88) stated inter alia the following with respect to the minimum standards for the provision of complementary medicine: where complementary medicines are offered for sale, staff involved must be trained in the use thereof; the client must be given appropriate information about the use and effectiveness of complementary medicine sold to them; and the client must be informed of possible adverse reactions and drug/drug and drug/food interactions. It is furthermore stated that information about complementary medicine must be suitable for the needs of specific groups of clients and must not make claims, which in the pharmacist's judgement, are misleading or speculative (South Africa, 2004:88). It is therefore of critical importance that pharmacists (and pharmacy students) are adequately trained in complementary medicine and practices in order to provide these products/services and the associated counselling to customers.

\section{Definitions of Complementary and Alter- native Medicine (CAM) and Complemen- tary and Alternative Health Care (CAHC)}

The term "alternative" has come to embrace any medical discipline and/or philosophy that is generally regarded as falling outside of the established biomedical model (Nienstedt, 1998:13) or that is outside the mainstream of western medicine (allopathic medicine) as practiced by the majority of medical doctors today (Stanway, 1979:12). Alternative medicine has also been defined as "Almost any form of alternative therapy, which falls outside conventional modern medicine" (Mattheus, 2004:12). Complementary medicine is often used synonymously with alternative medicine and suggests that the procedures complement treatments that are considered to be conventional (Mattheus, 2004:19).

Alternative (also known as complementary, natural, unconventional, unorthodox, holistic, traditional or integrative) therapies encompass a broad spectrum of practices and beliefs (Nienstedt, 1998:13). In North America, the phrase "alternative" is used interchangeably with terms like holistic medicine (Smith, Burman \& Boon, 1996:36-42). Also in South Africa, the term "holistic" is used both by complementary therapists and by some medical practitioners (Fenn, 1998:8). Allopathic health care using both biological and psycho- 
logical treatment methods is considered to be holistic in nature. In parts of the world where these unconventional disciplines are commonly used within the mainstream medical model, the more appropriate term of "complementary" medicine is in greater use (Smith et al. 1996:36-42), suggesting their use alongside allopathic medicine. In other words, the term "complementary medicine" is used to describe the cooperative effort between biomedicine and alternative practitioners in pursuit of their patients' good health and well-being (Nienstedt, 1998:14). The term "complementary" can therefore be regarded as an appropriate term, since it does not seek to deny the patient access to modern medicine. Yet it acknowledges that modern medicine does have its limitations and complementary therapies can offer something beyond what may be achieved with conventional treatments alone.

Another distinction can be made, namely between complementary and alternative medicine (CAM) and complementary and alternative health care (CAHC). Some researchers interpret the term "medicine" as only referring specifically to medicine, whereas "health care" implies all kinds of diagnosis, treatment and/or prevention of disease. These two terms will be used interchangeably in this manuscript due to the fact that, although CAHC may be the more appropriate and technically correct term to use, the survey conducted used the words Complementary and Alternative Medicine.

The line between alternative and conventional therapies has never been razor-sharp. It has evolved over time, and is still developing and changing. The inspiration for numerous alternative therapies comes in part from "classical folk medicine" or "indigenous medicine". Some of these therapies date back hundreds or even thousands of years. Almost every country has its own traditional medical system from which its alternative therapies originated. For the Chinese, for example, it is acupuncture, for the French, magnetic healing, for the Germans, Heilpraxis, for the British, herbalism, and in Africa, traditional African healers. It would be incorrect, for example, to refer to acupuncture as "alternative medicine" in China when one considers that most of China's population uses it as a primary form of health care. It would likewise seem strange to refer to homeopathic medicine as "alternative medicine" in Europe when almost $40 \%$ of French doctors and $20 \%$ of German doctors use these natural medicines in their practice, when $42 \%$ of British physicians refer patients to homeopathic doctors, and $45 \%$ of Dutch physicians consider homeopathic medicines to be effective (Gordon, Nienstedt \& Gesler, 1998:xi). What exactly constitutes CAHC may therefore vary according to national differences and individual viewpoints. The legal status of practitioners of $\mathrm{CAHC}$ therapies also varies around the world.

It can further be argued that herbal medicine actually works no different from any other allopathic medicine from a biological perspective. For example, morphine and digoxin are both from plant origin (as is a large percentage of all allopathic medicines) and work by acting on molecules (receptors or enzymes) in the body as do herbal medicines. It may therefore be not perfectly correct to state that CAHC falls outside the established biomedical model as was stated in the introductory definition, since although it may be true for some therapies, it certainly is not true for all therapies. An important difference, however, is that the basic pharmacology (pharmacodynamics and pharma-cokinetics) and clinical pharmacology (efficacy and safety) of allopathic medicine have been studied extensively by sound scientific means, whereas this has usually not been done in the case of herbal medicines. In addition, herbal medicines usually consist of a mixture of sometimes unknown substances or in unknown or variable concentrations. For these herbal medicines, the problem is not a matter of effectiveness versus ineffectiveness, or safety versus lack of safety, but merely that no evidence exists for their effectiveness and safety profiles from scientific investigation. In summary, it can thus be stated that knowledge about allopathic medicine is the result of sound scientific investigation, whereas knowledge about CAHC is obtained from often insufficient scientific investigation and/or from experience and/ or from belief systems. It may therefore be more appropriate to refer to complementary and alternative therapies as part of health care practice, and not as part of health science. Yet, it may be practiced in collaboration with science and make use of scientific knowledge in some or other way. This does not mean that complementary and alternative therapies are inferior, merely that it has no comprehensive or sufficient scientific basis (in the true sense of the criteria for pure scientific research).

For the purposes of this study, CAM/CAHC was defined as "diagnosis, treatment and/or prevention which 
complements mainstream medicine by contributing to a common whole, satisfying a demand not met by orthodoxy, or diversifying the conceptual framework of medicine" (Ernst et al. 2001:2).

\section{Spectrum of CAHC therapies}

A wide spectrum of alternative therapies exists. Some therapies are well-known. Other therapies are extremely controversial with no or limited proof, and can even endanger the health of patients. Furthermore, some of these therapies also appear to be in decline, while other newer ones are climbing the ladder of popularity. It is important for pharmacists to have a basic knowledge of these therapies in order to counsel patients effectively. The therapies listed in Table 1 can be regarded as 20 of the most well-known CAHC therapies in existence today.

There is also a range of therapies that are practiced, but for which insufficient evidence of their effectiveness exists in the literature. These therapies include, inter alia, anthroposophical medicine, art therapy, autologous blood therapy, the Bowen technique, colonic irrigation (colon therapy or hydrotherapy), colour therapy (light or photo therapy), crystal therapy (crystal healing or gem therapy), dance or movement therapy, enzyme therapy, the Feldenkrais method, flotation therapy, Hellerwork (structural integration), imagery (guided imagery or visualization), magnetic field therapy, meditation (or transcendental meditation), music therapy, neural therapy, Neurolinguistic Programming (NLP), oxygen therapy, ozone therapy, polarity therapy, Qi gong, Reiki, Rolfing (or structural integration), Shiatsu,
Tragerwork and water injection (Ernst et al. 2001:7981). Not all these therapies are necessarily detrimental to the health of patients - they are only listed due to insufficient evidence or proof in the literature that they are effective.

\section{Role of the pharmacist in CAHC}

Community pharmacy in South Africa is in transition. The profession has been moving away from the pure dispensing of prescriptions and the provision of basic health care, to actively engaging in the pharmaceutical care of its patients. According to Naidoo (1995:88), there appears to be a growing need for pharmacists in the new South African situation to look beyond the fringes of orthodox health care practices, and to attain some perspective on those practices that have a direct or indirect bearing on the pharmaceutical practitioner. The education and training of pharmacy students must therefore also adapt to the pharmacist's new role. The role of the pharmacist in South Africa with respect to CAHC is, however, not well documented. A recent study of community pharmacies in Johannesburg found that alternative medicines are sold in $85 \%$ of pharmacies, consultations take place in $65 \%$ and an alternative healer is available on the premises in nine percent (Gilbert, 2001:72). The nature and extent of these practices varied according to the location of the pharmacy and the demand in the area.

It has been said that alternative therapies intended to complement rather than replace conventional therapeutic interventions are more likely to find greater acceptability among health care professionals (Naidoo,

Table 1: Twenty well-known CAM therapies in existence today (Ernst et al. 2001:26-78)

\begin{tabular}{|l|l|}
\hline Acupuncture & Homeopathy \\
\hline Alexander technique & Hypnotherapy \\
\hline Aromatherapy & Massage \\
\hline Autogenic training & Naturopathy \\
\hline Bach flower remedies & Osteopathy \\
\hline Biofeedback & Reflexology \\
\hline Chelation therapy & Relaxation therapy \\
\hline Chiropractic & Spiritual healing \\
\hline Craniosacral therapy & Tai chi \\
\hline Herbalism & Yoga \\
\hline
\end{tabular}


1995:90). The community pharmacist's awareness in this regard is important not only as a purveyor of products which fall into the category of some alternative practices, but mainly because of the role as mediator in the health interest of the public (Naidoo, 1995:90).

The South African population is exposed to a variety of promotional material on CAHC and as they become more knowledgeable, they will also insist on a more critical and health-orientated pharmacist who has an overview of conventional and alternative therapies and their outcomes. A critical pharmacist can be described as one who can think and act constructively in relation to various theories of illness and health, and various methods of treatment and health promotion (Launsø, 1995:51).

Similar to allopathic medicine, CAHC practices pose some potential danger if used indiscriminately. Pharmacists must promote awareness that some CAHC practices, especially herbal medicines, are not necessarily safe just because they are "natural". Herbal medicine may also have side effects, contraindications and cause drug interactions. The same apply for many of the other CAHC practices, that may in some way or another be harmful to patients. Furthermore, if CAHC is not practiced wisely it may delay the initiation of appropriate allopathic health care, which can be detrimental in some cases. Health care workers and the public need to be educated in this regard.

It will therefore be necessary for pharmacists to develop insights into the potential and limitations of various theories and methods of treatment in relation to relieving and curing people's suffering and illnesses. This implies that an awareness of alternative therapies and their outcomes should be included alongside conventional therapies in the undergraduate pharmacy curriculum.

\section{Training of pharmacy students in CAHC}

Despite the increased interest in $\mathrm{CAHC}$, its principles are not extensively covered in the undergraduate pharmacy curriculum at South African universities. According to the literature (Miederhoff et al. 1999:94; Miller \& Murray, 1997:160-162), by 1979 most schools of pharmacy in the USA had discontinued pharmacognosy instruction. Similarly, most South African pharmacy schools trained students in subjects such as pharmacognosy until a few years ago. This provided students with an awareness of the importance of plants, including indigenous plants, in the treatment of disease and provided a basis for understanding herbalism. These subjects, however, had to make place for newer and other subjects, depriving students of the opportunity to realise the potential and important role of natural products in health care. Although many South African universities are actively engaged in research relating to some or other aspect of CAHC, not all pharmacy schools in South Africa include CAHC as a compulsory part of their undergraduate curriculum.

The basic principles of $\mathrm{CAHC}$ were introduced as an elective module in the final-year B Pharm curriculum at the University of Port Elizabeth (UPE) for the first time in 1996. This module was designed to develop students' understanding of the social forces behind the CAHC movement, as well as an understanding of the various modalities of alternative care. The module covered topics such as the role of the traditional African healer, herbalism, the theoretical basis and rationale for a range of well-known therapies (for example, aromatherapy and acupuncture), various mind-body therapies, as well as aspects related to nutrition from an alternative point of view. Although most of the module was lectured formally, small group discussions and active participation by students were encouraged. Students were also required to do a practical assignment on one of the topics covered in the elective and to present it at a seminar.

The demand for this elective module increased steadily, and since 2002 the principles of CAHC have been taught as part of the compulsory final-year Pharmacy Practice curriculum. CAHC is included as part of the module "Professional Pharmacy Practice" which is offered during the second semester of the fourth year. Due to the interest in CAHC by students, it was decided to test the knowledge and perceptions of current undergraduate students in an attempt to determine whether the content and level of presentation are adequate.

In the study in the USA (Miederhoff et al. 1999:94-95), student responses to an Alternative Medicine elective at the Virginia Commonwealth University School of Pharmacy were examined. This elective course was designed to develop in students an understanding of 
the social forces behind the movement towards alternative health care practices, as well as an understanding of the various modalities of alternative care. Fifty percent of the instruction time in this elective course is devoted to alternative medicine in general and $50 \%$ to natural products. Various alternative modalities are covered, for example, chiropractic, osteopathy, acupuncture, homeopathy, naturopathy, massage therapy, healing touch, biofeedback and hypnosis. Practitioners of these and other modalities provide demonstrations and lead discussions on issues such as philosophy, educational requirements, efficacy, indications and contraindications (Miederhoff et al. 1999:95). Thirty-two students who were enrolled for the elective course were asked to respond to five open-ended questions regarding the usefulness of the course and recommendations for improvement. Ninety-four percent of the students indicated that the course was useful or very useful to their future practice of pharmacy. Overall, the students' responses to this elective were extremely positive, with $81 \%$ of students indicating that the course should be part of the core curriculum and all the students indicating that they would recommend the course to other students (Miederhoff et al. 1999:95). The results therefore suggested that pharmacy programmes should be prepared to meet students' demands for such information.

\section{PRIMARY AIM}

The primary aim of the study was to determine the knowledge and perceptions of CAHC amongst undergraduate pharmacy students, as well as to establish their training needs for $\mathrm{CAHC}$ at a pharmacy school in South Africa.

\section{SUBJECTS AND METHODS}

A short questionnaire was compiled, consisting of open and closed questions. A pilot study was conducted and minor changes were made to the questionnaire. The final survey was conducted amongst all undergraduate pharmacy students (first to fourth year) at the then University of Port Elizabeth (one of the previously eight pharmacy schools in South Africa) during October 2002. The name of the university has since been changed (after merging with the Port Elizabeth Technikon and the Port Elizabeth Campus of Vista University to the Nelson Mandela Metropolitan University (NMMU)).
Students' knowledge of CAHC, their usage of different CAHC therapies and the need for continuing education courses in $\mathrm{CAHC}$ were measured. Questionnaires were distributed to first- to fourth-year pharmacy students during one of their Pharmacy Practice lectures. The questionnaire is given in Appendix A. A total of 160 questionnaires were completed and analysed (see Table 2). Only students who attended these Pharmacy Practice lectures were included in the sample (there were approximately 240 students in total in the Pharmacy School at the time of the study).

All Pharmacy students at UPE/NMMU are required to accumulate a total of at least $\mathbf{2 8 0}$ hours working in a retail or hospital pharmacy from their second to their fourth year of study. It was decided to differentiate between the different years of study in order to determine whether there were any changes in students' knowledge and interest in $\mathrm{CAHC}$ as they progressed to the more senior years of study as well as in relation to the number of hours that they had worked (in other words, the extent of their exposure to the practice situation). The knowledge and perceptions of first-year students were also measured, although it is not compulsory for them to work in pharmacies. Furthermore, fourth-year students had already had one introductory CAHC lecture when the survey was conducted, and they were therefore not asked to define $\mathrm{CAHC}$ since the definition had already been covered during their first lecture. They, however, had no other lectures or training in CAHC. They were therefore, apart from the introductory lecture, academically on the same level with respect to $\mathrm{CAHC}$ as students in the other three years of pharmacy.

The questionnaires were coded and the data were analysed with MS Excel ${ }^{\circledR}$. Basic descriptive statistics were calculated.

\section{RESULTS AND DISCUSSION}

The term "Complementary and Alternative Medicine (CAM)" is used at UPE/NMMU and the same terminology will therefore be used when reporting on the results of the study. The researcher acknowledges that Complementary and Alternative Health Care (CAHC) may be a more descriptive term for possible future use especially if the international literature changes from using CAM to CAHC. The results are, however, reported 
Table 2: Demographic characteristics of participants

\begin{tabular}{|l|l|l|l|l|l|}
\hline \multirow{2}{*}{$\begin{array}{l}\text { YEAR OF } \\
\text { STUDY }\end{array}$} & \% GENDER DISTRIBUTION & \multicolumn{2}{|l|}{ ALL PARTICIPANTS } & AVERAGE NUMBER \\
\cline { 2 - 6 } & FEMALES & MALES & NUMBER & $\%$ & OF HOURS WORKED \\
\hline First & 41.9 & 58.1 & 31 & 19.4 & 136.3 \\
\hline Second & 72.9 & 27.1 & 59 & 36.9 & 160.3 \\
\hline Third & 78.7 & 21.3 & 47 & 29.3 & 499.1 \\
\hline Fourth & 73.9 & 26.1 & 23 & 14.4 & 865.1 \\
\hline TOTAL & 68.8 & 31.2 & 160 & 100.0 & - \\
\hline
\end{tabular}

Table 3: Common themes identified in the definitions of CAM

\begin{tabular}{|l|l|l|}
\hline RANK & THEME & FREQUENCY \\
\hline 1 & Natural medicine (or non-synthetic medicine) & 40 \\
\hline 2 & Herbals & 24 \\
\hline 3 & Alternatives to normal registered medicine & 18 \\
\hline 4 & Used in conjunction with prescription medicine & 16 \\
\hline 5 & Homeopathy & 14 \\
\hline 6 & Traditional African medicine & 10 \\
\hline 7 & Non-drug therapy & 7 \\
\hline 7 & Not Western medicine & 7 \\
\hline
\end{tabular}

with the terminology as used at the time of the study.

\section{Demographic characteristics of the par- ticipants}

A total of 160 questionnaires were completed. The number of students, their year of study, gender and the average number of hours worked in pharmacies are indicated in Table 2. Although students are only formally required to work in pharmacies from their second year, many of them start to work in their first year to obtain experience. The average number of hours indicated in Table 2 is cumulative, in other words, for fourth-year students, it will be the number of hours worked since they started to work in pharmacies in their second year. Although only 280 hours are required from second to fourth year, most students far exceed this number by the end of their fourth year.

As can be seen in Table 2, the majority of students in the study were females. This result was in agreement with the overall gender distribution of pharmacy students at UPE, namely that more female students compared to male students were enrolled for the $B$ Pharm degree. It can also be observed from Table 2 that senior students had worked more hours on average in pharmacies compared to first- and second-year students.

\section{Definition of CAM}

Participants were asked what they understand by the term "Complementary and Alternative Medicine" (CAM). Final-year students did not answer this question since they had already been given formal definitions of CAM during their first lecture of the CAM submodule. This question was therefore only answered by first- to thirdyear students. Only 101 of the 137 participants attempted to define CAM. The 101 definitions given were analysed qualitatively by identifying common themes. Table 3 gives a summary of the most frequently identified themes. 
The definitions were furthermore analysed in terms of their correctness and/or appropriateness. From this analysis, it was clear that first-year students had a limited knowledge or no knowledge of what CAM constitutes. As would be expected, third-year students were the most knowledgeable (fourth-year students did not answer this question). This finding is most probably due to the fact that third-year students had already worked, on average, 499.1 hours in a pharmacy setting, and had been exposed to these products and therapies during their practical hours.

Examples of definitions that were given are: "Healing the body through non-medicinal methods by encompassing the entire body, mind, soul. " (Third-year, female student who had worked 100 hours in a pharmacy.)

There were also some interesting definitions, for example: "These are the other non-formal disciplines of medicine that work hand in hand or can be used as substitutes for the formal medical therapy." (First-year, male student who had not worked any hours in a pharmacy.) "Traditional \& home-remedies perhaps. E.g.: Voodoo, use of roots \& plants". (Second-year, male student who had not worked in a pharmacy.) "Complementary medicine is medicine that is more expensive. Alternative medicine is generic medicine." (First-year, male student with no hours worked.)

\section{Knowledge of the different CAM therapies}

Participants were given a list of 20 CAM therapies in the questionnaire (based on what are considered in the literature to be some of the most well-known CAM therapies currently in existence) and were asked to indicate whether they know what each one is, in other words, whether they will be able to fairly accurately define what the specific CAM therapy entails. Although subjective, it was felt that if a student could define what a therapy is, the student would at least be able to understand what the therapy entails. The responses are given in

Table 4: Percentage of students with knowledge of the different therapies according to year of study

\begin{tabular}{|c|c|c|c|c|c|}
\hline \multirow[b]{2}{*}{ THERAPY } & \multicolumn{5}{|c|}{ YEAR OF STUDY } \\
\hline & $\begin{array}{l}\text { FIRST } \\
(n=31)\end{array}$ & $\begin{array}{l}\text { SECOND } \\
(\mathrm{n}=59)\end{array}$ & $\begin{array}{l}\text { THIRD } \\
(n=47)\end{array}$ & $\begin{array}{l}\text { FOURTH } \\
(n=23)\end{array}$ & $\begin{array}{l}\text { ALL } \\
(n=160)\end{array}$ \\
\hline Acupuncture & 64.5 & 57.6 & 89.4 & 78.3 & 71.3 \\
\hline Aromatherapy & 74.2 & 69.5 & 91.5 & 82.6 & 78.8 \\
\hline Ayurveda & 3.2 & 3.4 & 8.5 & 30.4 & 8.8 \\
\hline Bach flower remedies & 9.7 & 25.4 & 17.0 & 21.7 & 19.4 \\
\hline Chiropractic & 48.4 & 42.4 & 72.3 & 52.2 & 53.8 \\
\hline Colonic irrigation & 54.8 & 32.2 & 78.7 & 56.5 & 53.8 \\
\hline Crystal (quartz) therapy & 16.1 & 28.8 & 36.2 & 34.8 & 29.4 \\
\hline Diet therapy & 83.9 & 81.4 & 78.7 & 82.6 & 81.3 \\
\hline Herbal products & 96.8 & 94.9 & 95.7 & 91.3 & 95.0 \\
\hline Homeopathy & 41.9 & 64.4 & 80.9 & 95.7 & 69.4 \\
\hline |ridology & 16.1 & 5.1 & 21.3 & 47.8 & 18.1 \\
\hline Massage & 96.8 & 88.1 & 95.7 & 82.6 & 90.6 \\
\hline Naturopathy & 9.7 & 23.7 & 10.6 & 47.8 & 20.6 \\
\hline Reflexology & 48.4 & 61.0 & 80.9 & 82.6 & 67.5 \\
\hline Reiki & 6.5 & 15.3 & 19.1 & 39.1 & 18.1 \\
\hline Relaxation therapy & 77.4 & 83.1 & 76.6 & 73.9 & 68.1 \\
\hline Spiritual healing & 74.2 & 79.7 & 80.9 & 56.5 & 75.6 \\
\hline Tai chi & 32.3 & 25.4 & 38.3 & 39.1 & 32.5 \\
\hline Traditional African medicine & 83.9 & 78.0 & 83.0 & 82.6 & 81.3 \\
\hline Yoga & 71.0 & 69.5 & 87.2 & 60.9 & 73.8 \\
\hline
\end{tabular}


Table 4 according to students' level of study (expressed as the percentage of students who indicated that they know what the specific therapy entails). It can be seen that the most well-known therapies were herbal products (152 of the 160 participants, 95.0\%), followed by massage (145 participants, 90.6\%) and traditional African medicine and diet therapy (130 participants each, 81.3\%). The least known therapies were ayurveda, iridology, Reiki and Bach flower remedies.

The 160 students had knowledge of a total of 1771 therapies, in other words, they each had on average a knowledge of approximately 11 therapies. As could be expected, students who had worked more hours in pharmacies (senior students) were more knowledgeable with respect to the different CAM therapies than students with limited or no hours worked. Third- and fourth-year students had on average a knowledge of 12.4 therapies, whilst the average for second-year students was 10.3 therapies and for first-year students was 10.1 therapies (not shown in Table 4). This was to be expected, since none of the students had any training in CAM (except the introductory lecture to the fourthyear students to define CAM, as explained previously). Their knowledge about CAM was therefore based on what they were exposed to during their work in the community pharmacy setting.

\section{Usage of the different CAM therapies}

Participants were given the same list of 20 CAM therapies and were asked to indicate whether they had personally used the therapy before. The responses (indicated as the percentage of students who had used each therapy) are given in Table 5 according to their level of study. All the therapies in the list had been used. Massage was the therapy most often used. Nearly $60 \%$ of participants had used massage, followed by herbal products ( $45.0 \%$ of the participants). Iridology, ayurveda, colonic irrigation and naturopathy were the least often

Table 5: Percentage of students who have used the different therapies according to year of study

\begin{tabular}{|l|l|l|l|l|l|}
\hline \multirow{2}{*}{ THERAPY } & \multicolumn{4}{l|}{ YEAR OF STUDY } \\
\cline { 2 - 6 } & $\begin{array}{l}\text { FIRST } \\
(\mathbf{n}=\mathbf{3 1})\end{array}$ & $\begin{array}{l}\text { SECOND } \\
(\mathbf{n = 5 9})\end{array}$ & $\begin{array}{l}\text { THIRD } \\
(\mathbf{n}=\mathbf{4 7})\end{array}$ & $\begin{array}{l}\text { FOURH } \\
(\mathbf{n = 2 3})\end{array}$ & $\begin{array}{l}\text { ALL } \\
(\mathbf{n}=\mathbf{1 6 0})\end{array}$ \\
\hline Acupuncture & 0.0 & 5.1 & 8.5 & 8.7 & 5.6 \\
\hline Aromatherapy & 19.4 & 42.4 & 42.6 & 30.4 & 36.3 \\
\hline Ayurveda & 3.2 & 0.0 & 2.1 & 4.3 & 1.9 \\
\hline Bach flower remedies & 6.5 & 6.8 & 4.3 & 8.7 & 6.3 \\
\hline Chiropractic & 3.2 & 8.5 & 12.8 & 0.0 & 7.5 \\
\hline Colonic irrigation & 3.2 & 3.4 & 0.0 & 4.3 & 2.5 \\
\hline Crystal (quartz) therapy & 3.2 & 1.7 & 2.1 & 8.7 & 3.1 \\
\hline Diet therapy & 12.9 & 16.9 & 14.9 & 8.7 & 14.4 \\
\hline Herbal products & 38.7 & 50.8 & 44.7 & 39.1 & 45.0 \\
\hline Homeopathy & 12.9 & 20.3 & 23.4 & 26.1 & 20.6 \\
\hline Iridology & 0.0 & 0.0 & 2.1 & 4.3 & 1.3 \\
\hline Massage & 64.5 & 64.4 & 48.9 & 52.2 & 58.1 \\
\hline Naturopathy & 3.2 & 1.7 & 2.1 & 4.3 & 2.5 \\
\hline Reflexology & 12.9 & 3.4 & 14.9 & 21.7 & 11.3 \\
\hline Reiki & 3.2 & 3.4 & 2.1 & 8.7 & 3.8 \\
\hline Relaxation therapy & 25.8 & 49.2 & 27.7 & 34.8 & 36.3 \\
\hline Spiritual healing & 35.5 & 25.4 & 14.9 & 21.7 & 23.8 \\
\hline Tai chi & 6.5 & 1.7 & 4.3 & 0.0 & 3.1 \\
\hline Traditional African medicine & 29.0 & 22.0 & 14.9 & 4.3 & 18.8 \\
\hline Yoga & 6.5 & 20.3 & 21.3 & 4.3 & 15.6 \\
\hline
\end{tabular}


used CAM therapies. The students only had used approximately three different therapies each (the 160 students together used 508 therapies). The average number of therapies used per student was 2.9 therapies for first-year students, 3.5 for second-year students, 3.1 for third-year students and 3.2 for fourth-year students.

\section{Knowledge of the reasons for the use of three well-known trade name products}

The trade names of three well-known CAM products that were actively advertised in the popular media during the time of the study were given, and participants were asked to indicate the main disease state(s) and/ or symptom(s) for which the three products are used. The responses to this question were unsatisfactory.

\section{Moducare ${ }^{\circledR}$}

Moducare ${ }^{\circledR}$ is a patented formulation of sterols and sterolins (each capsule contains $20 \mathrm{mg}$ of plant sterols and $0.2 \mathrm{mg}$ of sterolins). It is promoted as a product to defend the immune system. Most of the third-and fourthyear students indicated that Moducare ${ }^{\circledR}$ is used mainly as an immune booster, while second-year students gave a variety of conditions, and first-years had basically no idea what it is used for. Six fourth-year students indicated that Moducare ${ }^{\circledR}$ is used in the treatment of HIV/ AIDS.

\section{Procydin ${ }^{\circledR}$}

Procydin ${ }^{\circledR}$ (proanthocyanadin $70 \mathrm{mg}$ ) is an antioxidant preparation. It may enhance peripheral circulation and assist in the treatment of arthritis, atherosclerosis or raised cholesterol (Smith, 2003:288). Most third-year students were of the opinion that Procydin ${ }^{\circledR}$ is used for arthritis, but they also mentioned a variety of other uses. Fourth-year students gave a wide variety of conditions, but no one condition could be singled out as of more importance. Most second-year students indicated that it is an antioxidant, and first-year students again had very little insight into its uses.

\section{Spirulina ${ }^{\circledR}$}

Spirulina is a natural energy supplement that may assist athletes with endurance and strength (Smith, 2003:285). It supports the immune system and is also a source of protein for vegetarians (Smith, 2003:285). Most third- and fourth-year students indicated that Spirulina ${ }^{\circledR}$ is mainly indicated for energy. First- and second-year students again gave a variety of disease states and conditions for which Spirulina ${ }^{\circledR}$ could be used.

\section{Perceptions of when CAM principles should be included in the undergraduate pharmacy curriculum}

Participants were asked to indicate in which year (or years) of study CAM should be covered in the B Pharm curriculum. The responses are indicated in Table 6 . If a participant indicated more than one year-level (for example, during third and fourth year), a weight of 0.5 was allocated to each year. The reason for using a weight of only "one" per student, is to prevent a student who marked all four years to have his or her answer count four times that of a student who only marked one year level when answering this question.

Overall, participants were of the opinion that CAM should be included during the third or fourth year of study towards the B Pharm degree. It was interesting to note that most third-years were of the opinion that it should be included in the fourth year, whilst fourth-years were of the opinion that the work should be covered during the third year. Only three of the $137(2.19 \%)$ participants who answered this question indicated that CAM should not be covered during the undergraduate pharmacy programme.

\section{Need for continuing education of CAM and the preferred format}

Participants were asked whether they would be interested in enrolling for continuing education courses and/ or workshops in CAM after completion of their B Pharm degree. The responses are given in Table 7. (Table 7 on page 14.)

Participants were lastly asked if they had any suggestions or comments regarding the knowledge and/or training of pharmacists or pharmacy students in CAM. Most participants did not make any suggestions. From those that did comment, themes were identified. The most often recurring themes were that CAM is a very interesting field, that students need more in-depth information, that alternative practitioners can be invited to present talks, that students need relevant references for further study, and that the pharmacist must be in a 
Table 6: Year level at which CAM should be included in the B Pharm curriculum

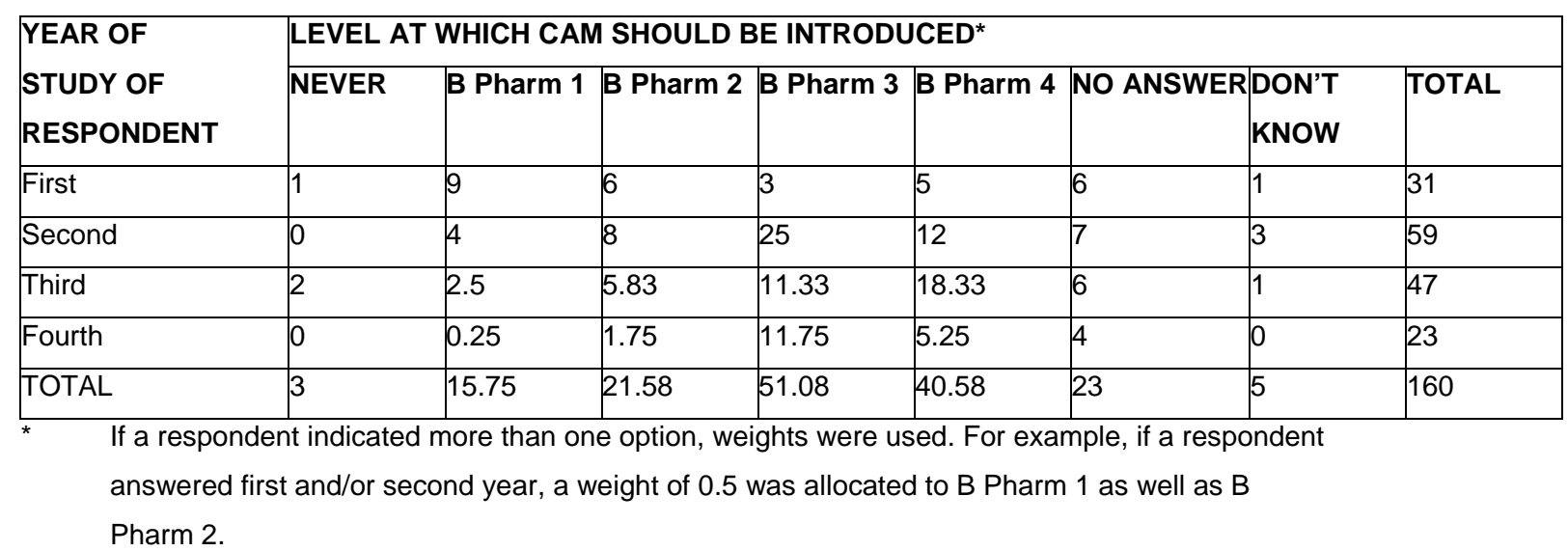

position to give an objective opinion regarding the use of these products and therapies.

\section{CONCLUSION AND RECOMMEN- DATIONS}

Pharmacists in South Africa are responsible for the pharmaceutical care of their patients, in other words, their goal is to attain an optimal health-related quality of life for their patients. There is a growing interest in more natural means to heal diseases, which has consequences for the pharmaceutical industry as well as community pharmacy over the long term. The progressive growth, for example, in the over-the-counter CAHC market worldwide is reflected in South Africa with total annual sales of approximately R2 billion, R140 million of which is on herbals (excluding indigenous herbs) (Smith, 2003:9). It therefore makes sense to include aspects of $\mathrm{CAHC}$ in the undergraduate curriculum, since pharmacists should ideally be au fait with all the therapies that are used by their patients in the prevention and treatment of disease and illness.

By educating undergraduate pharmacy students in the basic principles of the more well-known CAHC therapies and by creating an awareness of therapies that are not so familiar and possibly more controversial, young pharmacists will be in a better position to deliver optimal pharmaceutical care to their patients. Also, incorporating aspects of $\mathrm{CAHC}$ within the confines of a community pharmacy set-up, not only increases its accessibility to the public, but also creates the perception that it is part of the organised health care system and therefore strengthens the concept of holistic health care. It also fits the desired image of the community pharmacy as a health and wellness-promoting centre, and not only a business selling health-related products.

This study only tested the knowledge and perceptions of a selected group of pharmacy students and the findings cannot be generalised. However, after analysing the results the author is of the opinion that:

- A definite need exists for pharmacy students to be trained in the basic principles of CAHC. The current knowledge of students regarding $\mathrm{CAHC}$ is regarded as inadequate. In this study, students indicated that they were knowledgeable about (in other words, could fairly accurately define) on average 11 of the 20 most common CAHC practices. The depth of their knowledge was, however, not tested. Although some of the students may have an in-depth knowledge of the therapies, it may also be that many students have no more than just a "working definition knowledge" of the listed therapies. There are also many more therapies that were not listed in the questionnaire and that are actively practiced in South Africa that students need to be aware of.

- $\mathrm{CAHC}$ should be introduced in the third year of study, and more in-depth learning should take place during the fourth year. Especially aspects such as drug interactions with herbal products can better be dealt with when students' knowledge of pharmacology is on a more advanced level.

- There is a need for continuing education 
Table 7: Interest in continuing education in CAM after completion of B Pharm degree according to year of study

\begin{tabular}{|c|c|c|c|}
\hline \multicolumn{2}{|c|}{$\begin{aligned} \text { LEVEL OF STUDY CONTINUING EDUCATION } \\
\text { COURSES/ MODULES }\end{aligned}$} & $\begin{array}{l}\text { WORKSHOPS (DURING } \\
\text { WEEKENDS OR EVENINGS) }\end{array}$ & $\begin{array}{l}\text { BOTH MODULES AND } \\
\text { WORKSHOPS }\end{array}$ \\
\hline FIRST YEA & & & \\
\hline Yes & 12 & 15 & 13 \\
\hline No & 3 & 3 & 4 \\
\hline Not Sure & 12 & 7 & 11 \\
\hline No answer & 4 & 6 & 3 \\
\hline \multicolumn{4}{|c|}{ SECOND YEAR } \\
\hline Yes & 24 & 31 & 19 \\
\hline No & 10 & 5 & 12 \\
\hline Not Sure & 17 & 15 & 15 \\
\hline No answer & 8 & 8 & 13 \\
\hline \multicolumn{4}{|c|}{ THIRD YEAR } \\
\hline Yes & 21 & 18 & 18 \\
\hline No & 2 & 9 & 8 \\
\hline Not Sure & 16 & 12 & 17 \\
\hline No answer & 8 & 8 & 4 \\
\hline \multicolumn{4}{|c|}{ FOURTH YEAR } \\
\hline Yes & 19 & 12 & 14 \\
\hline No & 1 & 4 & 3 \\
\hline Not Sure & 0 & 2 & 2 \\
\hline No answer & 3 & 5 & 4 \\
\hline \multicolumn{4}{|l|}{ ALL YEARS } \\
\hline Yes & 76 & 76 & 64 \\
\hline No & 16 & 21 & 27 \\
\hline Not Sure & 73 & 36 & 56 \\
\hline No answer & 23 & 29 & 35 \\
\hline
\end{tabular}

courses/modules in CAHC in order to ensure that the knowledge of practising pharmacists stays current and up-to-date.

It is recommended that a survey of practising pharmacists also be conducted to determine the need for train- ing in the basic principles of CAHC, the specific topics that should be included, as well as the level at which this training should be provided.

The elective course in Complementary and Alternative Medicine (CAM) has been reintroduced at the new 
Nelson Mandela Metropolitan University from 2005 due to numerous demands from students for more in-depth training in this area. The newly designed elective is presented in a revised format with more emphasis on practical examples and it includes workshop sessions with practitioners.

\section{ACKNOWLEDGEMENTS}

The financial assistance of the Medical Research Council (MRC) towards this research is hereby acknowledged. Opinions expressed in this paper and conclusions arrived at, are those of the author and are not necessarily to be attributed to the MRC.

Ms Mea van Huyssteen for her help with the capturing and analysis of the data.

Mrs Samantha Venter for assisting in proofreading the manuscript.

Appendix $\mathrm{A}$ is on page 16 .

\section{REFERENCES}

EBEY-TESSENDORF, K; KRETZMANN, G \& MOUTON, N 1997: Expanding the boundaries of the nursing curriculum: Should alternative medicine be included? Health SA Gesondheid, 2(1):17-21. ERNST, E; PITTLER, MH; STEVINSON, C \& WHITE, A eds 2001: The desktop guide to complementary and alternative medicine: An evidence-based approach. London: Mosby.

FENN, C 1998: A Guide to Complementary Therapies in South Africa. Cape Town: Struik.

GILBERT, L 2001: Alternative medicine in the community pharmacy: A case study of community pharmacies in Johannesburg, South Africa. Journal of Social and Administrative Pharmacy, 19(2):72-80.

GORDON, RJ; NIENSTEDT, BC \& GESLER, WM 1998: Alternative therapies: Expanding options in health care. New York: Springer. LAUNSØ, L 1995: People choose alternative therapies - The consequences for future pharmacy practice. Journal of Social and Administrative Pharmacy, 12(1):43-52.

MATTHEUS, E 2004: The informed choice: The A-Z guide to the natural treatment of body, mind and spirit. Rondebosch: Kima Global.

MIEDERHOFF, PA; WRIGHT, SS; BURUSS, R \& WEAVER, W 1999 : Description and evaluation of an alternative medicine elective. Journal of Social and Administrative Pharmacy, 16(2):9495.

MILLER, LC \& MURRAY, WJ 1997: Herbal instruction in US schools of pharmacy. American Journal of Pharmaceutical Education, 61:160-162.

NAIDOO, NT 1995: Holism in Health care. South African Pharmaceutical Journal, March:88-90.

NIENSTEDT, BC 1998: The definitional dilemma of alternative medicine. (In: GORDON, RJ; NIENSTEDT, BC \& GESLER WM 1998: Alternative therapies: Expanding options in health Care. New York: Springer).

NOVEY, DW 2000: Clinician's Complete reference to complementary/alternative medicine. St. Louis: Mosby.

PLUSFILE 2000: Phytomedicines. Cramerview: PLUS Continuing Pharmacy Education programme. Module 4(September):1-20. SMITH, M; BURMAN, D \& BOON, H 1996: Alternative medicine: A survival guide for pharmacists. CPJ/RPC, July/August:36-42. SMITH, PR ed 2003: MediCAMS Index: Your guide to complementary medicine. Vol. 1. Cape Town: MediCAMS.

SOUTH AFRICA 2004: Rules relating to good pharmacy practice. Board Notice 129 of 2004 of The South African Pharmacy Council. Government Gazette No. 27112, 17 December 2004.

STANWAY, A 1979: Alternative medicine: A guide to natural therapies. London: Bloomsbury Books. 
Appendix A: Questionnaire

DEPARTMENT OF PHARMACY

QUESTIONNAIRE

COMPLEMENTARY AND ALTERNATIVE MEDICINE : KNOWLEDGE OF PHARMACY STUDENTS

Please mark the appropriate block with an " $X$ " or write your answer in the space provided:

Year of study:

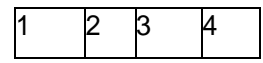

Gender:

\begin{tabular}{|l|l|}
\hline Female & Male \\
\hline
\end{tabular}

Total number of hours that you have worked in a pharmacy: hours

What do you understand under the term "Complementary and Alternative Medicine"?

Indicate whether you know (that is, will be able to fairly accurately define) what each of the following therapies involves, as well as whether you have personally used the therapy before:

\begin{tabular}{|l||l|l||l|l||}
\hline THERAPY & \multicolumn{2}{|l||}{ KNOW } & \multicolumn{2}{l||}{ LAVE } \\
& WHAT IT IS & \multicolumn{2}{|l||}{ USED IT } \\
\cline { 2 - 5 } & Yes & No & Yes & No \\
\hline Homeopathy & & & & \\
\hline Reflexology & & & & \\
\hline Aromatherapy & & & & \\
\hline Bach Flower Remedies & & & & \\
\hline Herbal products & & & & \\
\hline Ayurveda & & & & \\
\hline Chiropractic & & & & \\
\hline Yoga & & & & \\
\hline Reiki & & & & \\
\hline Acupuncture & & & & \\
\hline
\end{tabular}

\begin{tabular}{|l||l|l||l|l||}
\hline THERAPY & \multicolumn{2}{|l||}{ KNOW } & \multicolumn{2}{l||}{ HAVE } \\
& WHAT IT IS & \multicolumn{2}{l||}{ USED IT } \\
\hline & Yes & No & Yes & No \\
\hline Colon irrigation & & & & \\
\hline Iridology & & & & \\
\hline Diet therapy & & & & \\
\hline Crystal (quartz) therapy & & & & \\
\hline Tai chi & & & & \\
\hline Traditional African Medicine & & & & \\
\hline Massage & & & & \\
\hline Relaxation therapy & & & & \\
\hline Naturopathy & & & & \\
\hline Spiritual healing & & & \\
\hline
\end{tabular}

What are the main disease state(s)/symptom(s) for which the following products are used?

Moducare ${ }^{\circledR}$ :

Procydin ${ }^{\circledR}$ :

Spirulina ${ }^{\circledR}$ :

In which year(s) of study should Complementary and Alternative Medicine be covered in the B Pharm curriculum?

Would you be interested to enrol for continuing education courses and/or workshops in Complementary and Alternative Medicine after completion of your B Pharm degree?

\begin{tabular}{|l|l|l|l|}
\cline { 2 - 4 } \multicolumn{1}{l|}{ Yes } & No & Not sure \\
\hline Continuing education courses/modules & & & \\
\hline Workshops (during weekends or evenings) & & & \\
\hline Both modules and workshops & & & \\
\hline
\end{tabular}

Any suggestions/comments on the knowledge and/or training of pharmacists or pharmacy students in Complementary and Alternative Medicine?

THANK YOU FOR YOUR WILLINGNESS TO COMPLETE THE QUESTIONNAIRE! 